\title{
Transformation of arsenic lipids in decomposing Ecklonia radiata
}

\author{
Ronald A. Glabonjat ${ }^{1}$ (D) Elliott G. Duncan ${ }^{2,3} \cdot$ Kevin A. Francesconi $^{1} \cdot$ William A. Maher $^{3}$
}

Received: 7 March 2019 / Revised: 31 May 2019 / Accepted: 7 June 2019 / Published online: 26 June 2019

(C) The Author(s) 2019

\begin{abstract}
To investigate the release and degradation of arsenolipids present in the marine brown macroalga Ecklonia radiata, tissues were collected in various stages of decomposition from intertidal environments, while tissues were also decomposed in laboratorybased microcosms prepared using combinations of autoclaved and natural (non-autoclaved) seawater and sand. Field collected macroalgae samples contained $20-120 \mu \mathrm{g} \mathrm{g}^{-1}$ total As of which 1-10\% were arsenolipids comprising mainly an arsenic hydrocarbon (AsHC; 3-13\% of total arsenolipids) and four di-acyl arsenic phospholipids (AsPLs; 86-95\%). Additionally, a mono-acyl AsPL was found in all water-column decomposing samples. Arsenolipid concentrations in live tissues were similar to those in tissues decomposing in the water-column (1.3-2.9 $\mathrm{\mu g} \mathrm{g}^{-1}$ dry mass), which were both up to four times higher than those in decomposing tissues collected from intertidal environments $\left(0.7-1.3 \mu \mathrm{g} \mathrm{g}^{-1}\right.$ dry mass). In the microcosm experiments, the arsenolipid content of $E$. radiata decreased substantially as decomposition proceeded. In the majority of microcosms, more than $75 \%$ of the arsenolipids present initially disappeared within 5 days with only the AsHC persisting until day 60 (the length of the experiment). This study demonstrates that the habitat in which decomposition occurs influences the release and degradation of arsenolipids with the greatest losses occurring when tissues decompose in intertidal environments. Microbial diversity, biomass, and overall activity are thus likely to play important roles in the persistence of arsenolipids in decomposing algae.
\end{abstract}

Keywords Arsenolipids $\cdot$ Biodegradation $\cdot$ Macroalgae $\cdot$ Microcosms $\cdot$ HPLC-ICPMS/ESMS

\section{Introduction}

Marine organisms naturally contain high concentrations of organic arsenic species (Edmonds and Francesconi 2003). Currently, more than 100 arsenic species have been identified with arsenoribosides the most common species in algae and arsenobetaine $(\mathrm{AB})$, the dominant species in most marine animals (Francesconi and Edmonds 1998; Rahman et al. 2012).

Electronic supplementary material The online version of this article (https://doi.org/10.1007/s10811-019-01845-2) contains supplementary material, which is available to authorized users.

Ronald A. Glabonjat

ronald.glabonjat@uni-graz.at

1 Institute of Chemistry, NAWI Graz, University of Graz, Universitaetsplatz 1, $8010 \mathrm{Graz}$, Austria

2 Environmental Contaminants Group, Future Industries Institute, University of South Australia, Mawson Lakes Boulevard, Mawson Lakes, SA 5095, Australia

3 Ecochemistry Laboratory, Institute for Applied Ecology, University of Canberra, University Drive, Bruce, ACT 2601, Australia
Many studies have investigated the cycling and biosynthesis of water-soluble As species in marine ecosystems (e.g., Santosa et al. 1994; Rahman et al. 2012; Hanaoka and Usui 2014; Maher et al. 2015; Foster and Maher 2016). Despite arsenic-containing lipids (arsenolipids; the major classes are depicted in Fig. S1) originally being identified over 30 years ago by Morita and Shibata (1988), far less information exists on the production and biosynthesis of arsenolipid species by marine organisms (Sele et al. 2012; Amayo et al. 2014; Petursdottir et al. 2015; Glabonjat et al. 2018). In recent years, however, there has been renewed interest in the characterization of arsenolipids in marine organisms; and as a result, over 80 arsenolipids including As-hydrocarbons (AsHCs) (Taleshi et al. 2008), As-fatty acids (Rumpler et al. 2008), As-fatty alcohols (Amayo et al. 2013), As-phospholipids (AsPLs) (Morita and Shibata 1988; Viczek et al. 2016), and methoxy As-sugar phytol (Glabonjat et al. 2017) have been identified from a range of organisms such as marine algae, squid, and fish.

Algae (macro and unicellular) play three important roles in the cycling of As in marine environments. Firstly, they are able to remove arsenic from the water-column and bio- 
transform inorganic As species (predominantly arsenate) to arsenoribosides and other organic As species such as methylarsonic acid (MA) and dimethylarsinic acid (DMA) (Rahman et al. 2012; Duncan et al. 2015). Secondly, as algae are the bases of most marine food webs, this accumulated and bio-transformed As is then transferred to higher marine organisms that utilize algae as a food source (Rahman et al. 2012; Foster and Maher 2016). Thirdly, the arsenic accumulated by algae is eventually returned to the environment when tissues decompose in the water column, or by active excretion of inorganic and methylated arsenic species, which represents an important link in the marine As-cycle (Hanaoka et al. 1995; Duncan et al. 2014a, b).

Previously, our group investigated the degradation of water-soluble As species associated with the marine macro-alga Ecklonia radiata when tissue decomposition occurred in the field and in laboratory microcosms (Duncan et al. 2014a, c). The current study complements those previous findings by utilizing the same tissue samples to investigate the fate of arsenolipids associated with decomposing E. radiata. Our objective was to determine how arsenolipid species present in E. radiata changed depending on the stage of decomposition and habitat (water-column, intertidal sand/rock platforms), and establish the potential roles played by microbial communities during the decomposition processes.

\section{Materials and methods}

\section{Live and naturally decomposing Ecklonia radiata}

Detailed information on the collection of Ecklonia radiata tissues can be found in the study of Duncan et al. (2014c). Ecklonia radiata samples were collected between 24 and 26 February 2012 at two estuaries, Lake Tabourie $\left(35.4486^{\circ} \mathrm{S}\right.$, $\left.150.4011^{\circ} \mathrm{E}\right)$, Burill Lake $\left(35.3886^{\circ} \mathrm{S}, 150.4447^{\circ} \mathrm{E}\right)$, and Ulladulla Harbor $\left(35.3667^{\circ} \mathrm{S}, 150.4667^{\circ} \mathrm{E}\right)$ in southern New South Wales, Australia. These locations were chosen because there are no arsenic contamination sources and all locations contained live E. radiata tissues plus E. radiata decomposing in the water-column. In addition, these sites also contained a combination of beach (i.e., sand) and rock platform environments, which we hypothesized, would significantly influence the extent of terrestrial decomposition of the algae and thus would result in different rates of degradation of arsenolipids. Five replicates of live $E$. radiata specimens (live; $n=5), E$. radiata tissues decomposing in the water-column (submerged; $n=5$ ), and E. radiata tissues decomposing on a sand/rock platform on the beach (beach; $n=5$ ) were collected at all three sampling locations. For the analysis of arsenolipids, replicates were pooled within each of the three sampling habitats (live, submerged, and beach).

\section{Microbially manipulated microcosms}

Details of the preparation of laboratory microcosms can be found in the study of Duncan et al. (2014a). In brief, E. radiata tissue, sand, and seawater were collected from one site at Bawley Point, New South Wales $\left(35.5199^{\circ} \mathrm{S}\right.$; $150.3967^{\circ} \mathrm{E}$ ). On return to the laboratory, three subsamples each of $E$. radiata, seawater, and sand were frozen for later use in the microcosm experiments.

Microcosms were created using $225 \mathrm{~cm}^{2}$ nonpyrogenic tissue culture flasks (Corning, USA) containing $E$. radiata tissue ( $2 \mathrm{~g}$ wet mass), sand (300 g dry mass, either autoclaved or natural), and seawater $(600 \mathrm{~mL}$, either autoclaved or natural), which were added to each flask under aseptic conditions. Four sets of conditions, each done in triplicate, were used to establish the microcosms: (1) natural sand and seawater, (2) natural sand and sterile seawater, (3) sterile sand and natural seawater, and (4) sterile sand and sterile seawater. Microcosms were incubated at a light intensity of $110 \mu \mathrm{mol}$ photons $\mathrm{m}^{-1} \mathrm{~s}^{-1}$, under a 12:12 h light:dark ratio. Temperatures were maintained at $20{ }^{\circ} \mathrm{C}$ during dark periods ramping up to $25{ }^{\circ} \mathrm{C}$ during light periods. After incubation for 5 days, one set of samples $(n=3$ replicates) for each of the experimental treatments $(n=4) \quad(n=12$ microcosms in total) were randomly selected and removed from the chamber. This process was repeated at all time intervals (days 5, 10, 15, 20, $30,45$, and 60$)$. E. radiata tissues were removed and placed into $50-\mathrm{mL}$ centrifuge tubes (polypropylene; Greiner, USA), frozen and freeze-dried for later determination of total arsenic and arsenic species. For the analysis of arsenolipids, replicates from each sampling time were pooled; at some time intervals (natural sand and seawater: days 10,15 , and 30 ; sterile seawater: days 20,30, and 60; and sterile sand: day 15), there was insufficient algal biomass for arsenolipid measurements.

\section{Reagents and standards}

Water used for all analytical steps was obtained from a Milli-Q system (18.2 M $\Omega \mathrm{cm}$, Millipore $\mathrm{GmbH}$, Austria). Methanol $(\geq 99.9 \%, \mathrm{MeOH})$, dichloromethane $(\geq 99.9 \%$, DCM), formic acid ( $\geq 98 \%)$, acetone $(\geq 99.5 \%)$, and ammonia (25\%) were obtained from Carl Roth $\mathrm{GmbH}$ (Germany); acetone $(\geq 99.5 \%)$ was purchased from Sigma-Aldrich (Austria); and acetic acid (100\% glacial) and silica gel $60(0.063-0.200 \mathrm{~mm})$ were obtained from Merck (Switzerland). The certified reference material was NMIJ CRM 7405-a (Trace Elements and Arsenic Compounds in Seaweed - Hijiki) from the Natural Metrology Institute of Japan (Tsukuba, Ibaraki, Japan). 
Standard arsenolipids, namely AsHC332, AsHC360, and AsHC444 (structures are shown in Fig. S1), were synthesized in-house according to Taleshi et al. (2014), and standard solutions (each $0.1 \mathrm{mM}$ or $7.5 \mathrm{mg} \mathrm{L}^{-1}$ ) were prepared by dissolving the compound $(7.5 \pm 0.2 \mu \mathrm{g}$ as $\mathrm{As})$ in $\mathrm{MeOH}(1 \mathrm{~mL})$.

\section{Arsenolipid measurements}

The lipid arsenic species within E. radiata tissues were measured via high performance liquid chromatography (HPLC) coupled simultaneously to an inductively coupled plasma mass spectrometer (ICPMS) and an electrospray ionization mass spectrometer (ESMS) (Yu et al. 2018). The freeze-dried algal sample $(10 \mathrm{mg}$ weighed to a precision of $0.01 \mathrm{mg}$ ) was extracted with $\mathrm{DCM} / \mathrm{MeOH}(2+1, v / v ; 1 \mathrm{~mL})$ for $1 \mathrm{~h}$ on a rotary cross at room temperature. The mixture was centrifuged (10 min, $5000 \times g$ ), and a portion of the liquid phase $(0.7 \mathrm{~mL})$ was filtered $(0.2 \mu \mathrm{m}$; nylon) and injected onto the HPLC-system.

Separation of arsenolipid species was carried out by reversed-phase (RP) HPLC using an ACE UltraCore SuperC18 column $(4.6 \times 250 \mathrm{~mm}, 5-\mu \mathrm{m}$ particle size $)$. Elution was performed with water containing $25 \mathrm{mM}$ ammonium acetate (adjusted to $\mathrm{pH} 9.2$ with $\mathrm{NH}_{3}$; mobile phase A) and $\mathrm{MeOH}$ containing $25 \mathrm{mM}$ ammonium acetate (adjusted to $\mathrm{pH} 9.2$ with $\mathrm{NH}_{3}$; mobile phase B) under gradient elution conditions: $0-40 \mathrm{~min}, 20-100 \%$ B; 40-53 min, $100 \% \mathrm{~B}$; 53-53.5 min, $100-20 \% \mathrm{~B}$; and

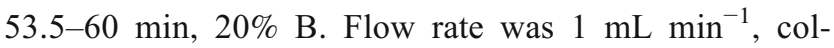
umn temperature was $40{ }^{\circ} \mathrm{C}$, and injection volume was $50 \mu \mathrm{L}$. For ICPMS detection, the HPLC effluent was split whereby $10 \%$ were transported to the ICPMS (to maintain a stable plasma by reducing the organic solvent load) using a passive splitter (Analytical Scientific Instruments, Richmond, USA) and post-splitter support of the outflow with water containing $1 \% \mathrm{v} / \mathrm{v}$ formic acid and internal standards $\mathrm{Ge}$, In, and Te $\left(20 \mu \mathrm{g} \mathrm{L}^{-1}\right.$; $0.9 \mathrm{~mL} \mathrm{~min}^{-1}$ ) through a T-piece. Carbon compensation (Raber et al. 2010) was performed by constant introduction of an aqueous acetone solution $(5 \% \mathrm{v} / \mathrm{v}$ in water) directly into the spray chamber delivered with a rotatory pump $\left(0.2 \mathrm{~mL} \mathrm{~min}{ }^{-1}\right)$ to ensure constant carbon content reaching the plasma. Limit of detection (LOD) and limit of quantification (LOQ) of the HPLC-ICPMS method were $0.01 \mu \mathrm{g} \mathrm{As} \mathrm{g}^{-1}$ dry mass (based on three blank extracts $+3 \times$ standard deviation of the blank) and $0.05 \mu \mathrm{g} \mathrm{As} \mathrm{g}^{-1}$ dry mass (based on three blank extracts $+10 \times$ standard deviation of the blank), respectively. Lipid extracts were measured on an Agilent 7900 instrument. For ESMS detection, the remaining $90 \%$ of the HPLC effluent was directly introduced to the ion source of an Agilent 6460 instrument equipped with a Jetstream ion source operated in positive ionization mode using a capillary voltage of $5 \mathrm{kV}$ and nozzle voltage of $2 \mathrm{kV} ; \mathrm{N}_{2}$ gas temperature was $350{ }^{\circ} \mathrm{C}$ with a flow of $12 \mathrm{~L} \mathrm{~min}^{-1}$; nebulizer pressure was $25 \mathrm{psi}$; and sheath gas temperature was $350{ }^{\circ} \mathrm{C}$ with a flow of $11 \mathrm{~L} \mathrm{~min}^{-1}$. Arsenolipid species were extracted from either SCAN mode observing a mass range of $\mathrm{m} / \mathrm{z} 150-1100$ with a scan time of $0.5 \mathrm{~s}$, and fragmentor voltages of $135 \mathrm{~V}$ and $200 \mathrm{~V}$; or determined in MRM mode with dwell times of $0.1 \mathrm{~s}$ per transition using the conditions described in Table S1.

In addition to the simultaneous determination by RPHPLC-ICPMS/ESMS, we also used high-resolution (HR) ESMS for the accurate measurement of arsenolipid masses using a Thermo Q-Exactive Hybrid Quadrupole Orbitrap MS equipped with an HESI-II ion source (Thermo Scientific, USA). The HPLC system comprised an UltiMate 3000 system (Thermo Scientific). Freezedried E. radiata samples $(100 \mathrm{mg})$ were extracted with $\mathrm{DCM} / \mathrm{MeOH}(2+1, v / v ; 3 \mathrm{~mL})$ for $1 \mathrm{~h}$ on a rotary cross at room temperature. The mixture was centrifuged $(10 \mathrm{~min}, 5000 \times \mathrm{g})$ and a portion of the liquid phase $(2.7 \mathrm{~mL})$ evaporated to dryness $\left(100 \mathrm{mbar}, 25{ }^{\circ} \mathrm{C}\right)$, redissolved in $\mathrm{MeOH} /$ acetone $(1+1, v / v$, containing $1 \% \mathrm{v} / \mathrm{v}$ formic acid, $1 \mathrm{~mL}$ ), and transferred to a small column containing silica gel 60 (glass Pasteur pipette, $230 \times$ $5 \mathrm{~mm}$, filled to a height of $40 \mathrm{~mm}$ ), conditioned with the same mixture $(5 \mathrm{~mL})$. The column was washed with the conditioning solution $(5 \mathrm{~mL})$ and then with pure $\mathrm{MeOH}(2 \mathrm{~mL})$. Finally, arsenolipids were eluted with $\mathrm{MeOH}$ containing $1 \% \mathrm{v} / \mathrm{w} \mathrm{NH}_{3}(8 \mathrm{~mL})$ and evaporated to dryness $\left(10 \mathrm{mbar}, 25^{\circ} \mathrm{C}\right)$, and the residue stored at $-20{ }^{\circ} \mathrm{C}$. The residue was re-dissolved in pure $\mathrm{MeOH}$ $(200 \mu \mathrm{L})$ prior to measurement.

Chromatographic conditions were slightly different for HR-ESMS measurements owing to the need for higher sensitivity: HPLC-column was an Asahipak ODP-50 $(150 \times 4.6 \mathrm{~mm} ; 5 \mu \mathrm{m}$ particle size $)$; separation of arsenolipids was carried out using gradient elution conditions with a flow of $0.5 \mathrm{~mL} \mathrm{~min}{ }^{-1}$ using water containing $0.1 \% \mathrm{v} / \mathrm{v}$ formic acid (mobile phase $\mathrm{A}$ ) and $\mathrm{MeOH}$ containing $0.1 \% \mathrm{v} / \mathrm{v}$ formic acid (mobile phase B), 0-30 min, 60 $100 \% \mathrm{~B} ; 30-40 \mathrm{~min}, 100 \% \mathrm{~B}$; 40-40.1 min, $100-60 \% \mathrm{~B}$; and $40.1-50 \mathrm{~min}, 60 \% \mathrm{~B}$. The HPLC column was held at $40{ }^{\circ} \mathrm{C}$ and the injection volume was $20 \mu \mathrm{L}$. The HR-ESMS was operated under positive ionization conditions $(3.5 \mathrm{kV})$ in data dependent $\mathrm{MS}^{2}$ mode fragmenting the five most abundant peaks of each scan event (m/z 100-1200) with fragmentation energies of 20,35 , and 50 instrument units (IU). Resolution was set to 70,000 (FWHM) with an isolation window of $0.4 \mathrm{~m} / \mathrm{z}$ at the quadrupole; capillary temperature, $270{ }^{\circ} \mathrm{C}$; sheath gas flow, $52.5 \mathrm{IU}$; auxiliary gas flow, $14 \mathrm{IU}$; and probe temperature $438{ }^{\circ} \mathrm{C}$. 
Data evaluation of ICPMS measurements was carried out with the chromatographic software MassHunter B.01.01 obtained from Agilent Technologies (Germany). Quantification was based on peak areas with external calibration against standards of AsHC332, AsHC360, and AsHC444 for lipidsoluble arsenicals. ESMS data were evaluated with MassHunter Workstation B.07.00 from Agilent Technologies, and HR-ESMS data were evaluated with chromatographic software Xcalibur 3.0.63 from Thermo Scientific (USA). Accuracy of the arsenic speciation procedure was determined by analysis of the certified reference material NMIJ 7405 -a Hijiki prepared in the same way as E. radiata samples (Fig. S2 and Table S2). Identification of individual arsenolipids was based on retention time matching with CRM Hijiki (RP-HPLC-ICPMS/ESMS), as well as accurate mass determination with RP-HPLC-HR-ESMS (Table S3). Arsenolipid species found in E. radiata samples in this study are shown in Fig. 1.

\section{Total arsenic}

Total arsenic concentrations in naturally decomposing $E$. radiata tissues and in $E$. radiata decomposing in<smiles>CCCCCCCCCCCCCCCCCCC[Si](C)(C)O</smiles><smiles>CCCCCCCCCCCCCCCCCCC(=O)OCC(O)COP(=O)(O)OCC(O)COC1OC(C[As](C)(C)=O)C(O)C1O</smiles><smiles>CCCCCCCCCCCCCCCCCCCCCCCC(=O)OCC(COP(=O)(O)OCC(O)COC1OC(C[Si](C)(C)O)C(O)C1O)OC(C)=O</smiles><smiles>CCOCC(COP(=O)(O)OCC(O)COC1OC(C[Si](C)(C)=O)C(O)C1O)OCC</smiles><smiles>CCCCCCCCCCCCCCCCCCCCCCC(=O)OCC(COP(=O)(O)OCC(O)COC1OC(C[Si](C)(C)O)C(O)C1O)OC(=O)CC</smiles><smiles>CCCCCCCCCCCCCCCCCCCC(=O)OCC(COP(=O)(O)OCC(O)COC1OC(C[As](C)(C)=O)C(O)C1O)OC(=O)CC</smiles>

Fig. 1 Arsenic containing lipids found in Ecklonia radiata extracts. For unsaturated AsPL980, we show only one possible isomer of the lipophilic side-chains microbially manipulated microcosms were determined in our previous studies (Duncan et al. 2014a, c).

\section{Results and discussion}

\section{Arsenolipids present in live and naturally decomposing Ecklonia radiata tissues}

\section{Total arsenolipid concentrations}

For live $E$. radiata samples, total arsenolipid concentrations ranged between 1.28 and $2.17 \mu \mathrm{g} \mathrm{g}^{-1}$ dry mass (Fig. 2 and Table S4) across the three sampling locations, which represents ca $1-3 \%$ of the total As in the macroalga. This arsenolipid concentration range is consistent with that reported for other marine algae (García-Salgado et al. 2012; Raab et al. 2013; Glabonjat et al. 2014; Al Amin et al. 2018).

Total arsenolipid concentrations in decomposing $E$. radiata tissues collected in the water-column (submerged) ranged between 1.87 and $2.85 \mu \mathrm{g} \mathrm{g}^{-1}$ dry mass across the three sampling locations (Fig. 2 and Table S4). These values were comparable with, or even higher than, those found in the live algae, indicating that the arsenolipids are retained, at least initially, in the submerged E. radiata tissues. This is in contrast to the behavior of total arsenic, mostly consisting of water soluble As species, which decreased by $25-65 \%$ as a result of abiotic processes such as leaching occurring in the water column (Duncan et al. 2014c). As a consequence, the proportion of arsenic present as arsenolipids in the submerged algae (2-10\%) was two- to threefold higher than that found in the live algae.

Total arsenolipid concentrations in decomposing $E$. radiata tissue collected from intertidal environments (beach) ranged between 0.74 and $1.31 \mu \mathrm{g} \mathrm{g}^{-1}$ dry mass (4-6\% of total As) with similar concentrations present across all three locations (Fig. 2 and Table S4). These arsenolipid concentrations in algae collected from beach environments were lower than those in live and submerged $E$. radiata, which indicates that the arsenolipids were starting to degrade. The arsenolipids, however, were much more resistant to degradation than were the water-soluble arsenicals investigated in our previous study (Duncan et al. 2014c).

Fig. 2 Total lipid-soluble arsenic concentrations and distribution of individual arsenolipids at three stages of naturally degrading Ecklonia radiata collected at three locations. Concentrations were determined by RPHPLC-ICPMS $(n=1)$ 


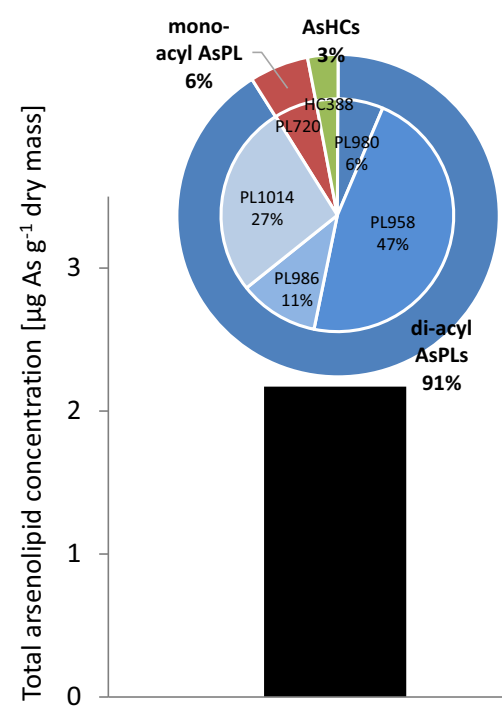

live

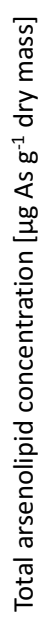

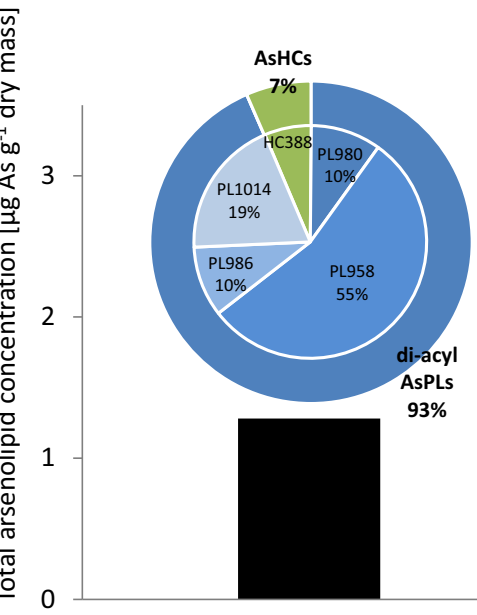

live

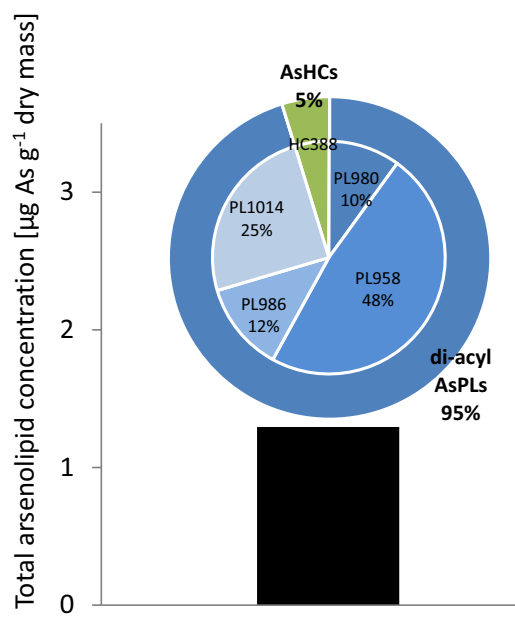

live
AsHCS
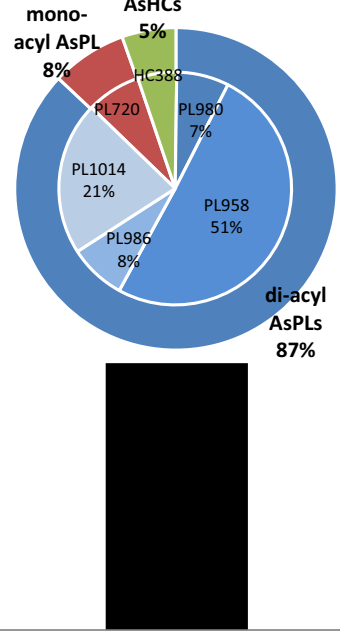

submerged

mono- AsHCs
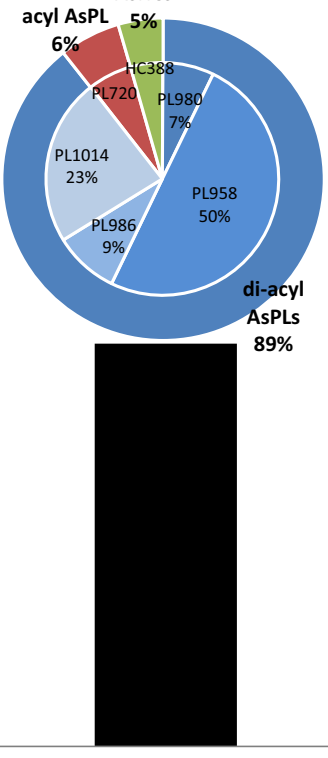

submerged
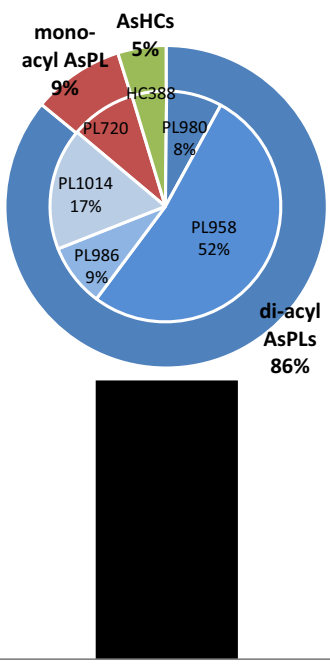

submerged
Burill Lake

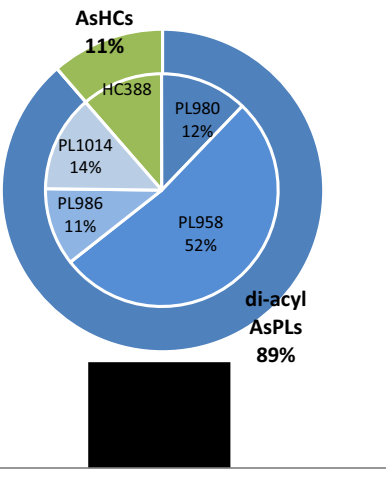

beach

Ulladulla Harbour
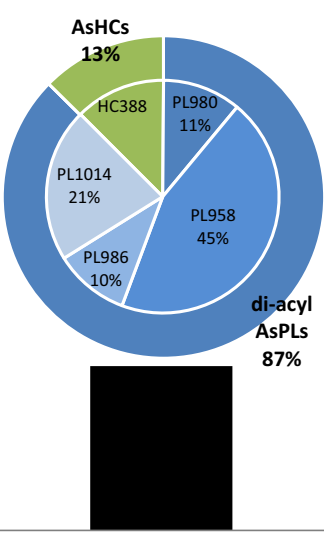

beach

Lake Tabourie
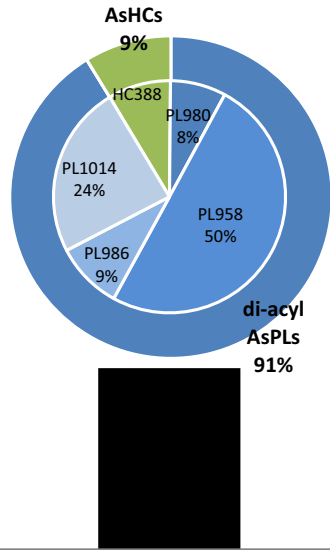

beach 


\section{Release and degradation of arsenolipid species}

All the E. radiata samples contained AsHC388, constituting 3-13\% of total arsenolipids, and four di-acyl AsPLs, which together made up $86-95 \%$ of the total arsenolipids, while mono-acyl AsPL720 (6-9\%) was mainly found in samples decomposing in the water column (submerged) (Fig. 2 and Table S4). The proportions of arsenolipid species in live E. radiata were similar across locations with AsPL958 the dominant species (48-55\%) followed by AsPL1014 (1927\%), AsPL986 (10-13\%), AsPL980 (6-11\%), and AsHC388 (3-6\%). All the arsenolipids found here have been reported previously in a range of macroalgal species (GarcíaSalgado et al. 2012; Raab et al. 2013; Yu et al. 2018) albeit in different proportions. Most studies have observed AsPLs to be abundant in macroalgae with lesser amounts of AsHCs (García-Salgado et al. 2012; Al Amin et al. 2018), although Petursdottir et al. (2015) observed the opposite pattern in Ectocarpus spp.

The proportions and concentrations of arsenolipids in decomposing E. radiata tissues collected in the water column (submerged) were similar to those found in live E. radiata tissues (Fig. 2, Fig. S2 and Table S4). There was, however, one exception: AsPL720 was present in all E. radiata tissues decomposing within the water-column, whereas this arsenolipid was only detected in one live algal sample (Fig. 2 and Table S4). Unlike the other AsPLs detected here, AsPL720 is a mono-acylated species and therefore it is likely to arise as a first stage degradation product of the di-acylated As-phospholipids. Mono-acyl arsenolipids have only rarely been reported in algae (Yu et al. 2018).

In extensively decomposed (beach) E. radiata tissue samples, the AsPLs remained in similar proportions to those in live and submerged tissues (Fig. 2 and Table S4). This pattern was maintained even in the Burill Lake samples where the total arsenolipid concentrations in beach algae were markedly lower than those in the live samples. In contrast, the proportion of AsHC388 increased more than twofold in the beach decomposing samples (live 3-6\%, submerged 4-6\%, beach 9-13\%) indicating that the AsHCs were more resistant to degradation than were the AsPLs. But overall, the arsenolipids were relatively stable in decomposing algal tissue, and thus their fate was markedly different from the fate of the watersoluble arsenic species, mainly arsenoribosides, which readily degraded under the same conditions (Duncan et al. 2014c).

\section{Arsenolipids in Ecklonia radiata decomposing in microbially manipulated microcosms}

\section{Total arsenolipid concentrations}

Initial total arsenolipid concentrations in the field collected E. radiata tissue was ca $3 \mu \mathrm{g} \mathrm{As}^{-1}$ dry mass. The total lipid-soluble As in all microcosms decreased by more than $75 \%$ during the first 5 days of incubation, and by the conclusion of the experiments (day 60), less than $10 \%$ of the initially present arsenolipids was present in the decomposing E. radiata tissues (Fig. 3 and Table S5). These rates of degradation were much faster than those observed for the fieldbased experiments, presumably reflecting increased microbial activity in the microcosms. We observed the fastest and most constant release of arsenolipids from $E$. radiata tissues under conditions with natural sand and seawater (Fig. 3 and Table S5).

\section{Release and degradation of arsenolipid species}

In live $E$. radiata, the proportions of arsenolipids were AsHC (11\%; $0.35 \mu \mathrm{g} \mathrm{As} \mathrm{g}^{-1}$ dry mass), mono-acyl AsPL (6\%; $0.20 \mu \mathrm{g} \mathrm{As} \mathrm{g}^{-1}$ ), and di-acyl AsPLs (83\%; $2.63 \mu \mathrm{g} \mathrm{As}^{-1}$ ) with the major components being AsPl958, AsPl980, As PL986, AsPL1014, AsHC388, and AsPL720 (Fig. 3, Fig. S2 and Table S5). In microcosms with natural sand and seawater, the concentrations of AsHC and di-acyl AsPLs reduced by 55 and $85 \%$, respectively after the first 5 days; while the mono-acyl AsPL720 was not detected in any decomposing tissue sample (Fig. 3 and Table S5). This rapid loss of arsenolipids was similar to that found for water-soluble arsenicals in decomposing algae as reported in our previous study (Duncan et al. 2014a) and by others (Edmonds et al. 1982; Pengprecha et al. 2005; Navratilova et al. 2011; Ojo and Onasanya 2013). By the latter stages of the experiment (days 45-60), almost all the AsPLs had degraded and only AsHC388 was detected in measurable concentrations (Fig. 3 and Table S5). This finding is consistent with the data described earlier from the field collected E. radiata, which showed that the AsHCs were more resistant to degradation than the AsPLs.

In the three microcosms using sterile sand, sterile seawater, or a combination of both, the degradation of the arsenolipids was similar to that observed for the natural sand and seawater microcosm, albeit less extensive. The AsHCs were again more recalcitrant than the AsPLs; by the conclusion of the experiments, more than $90 \%$ of all AsPLs had degraded whereas up to $50 \%$ of the AsHCs remained associated with the E. radiata tissues (Fig. 3 and Table S5). The similarity in arsenolipid degradation across the various treatments (natural sand and seawater versus sterile sand/seawater combinations) suggests that microbes associated with the surfaces of $E$. radiata may have re-colonized the initially sterile seawater and sand

Fig. 3 Total lipid-soluble arsenic concentrations and distribution of individual arsenolipids in Ecklonia radiata at various stages of degradation in microcosms under four sets of conditions. Concentrations were determined by RP-HPLC-ICPMS $(n=1)$ 


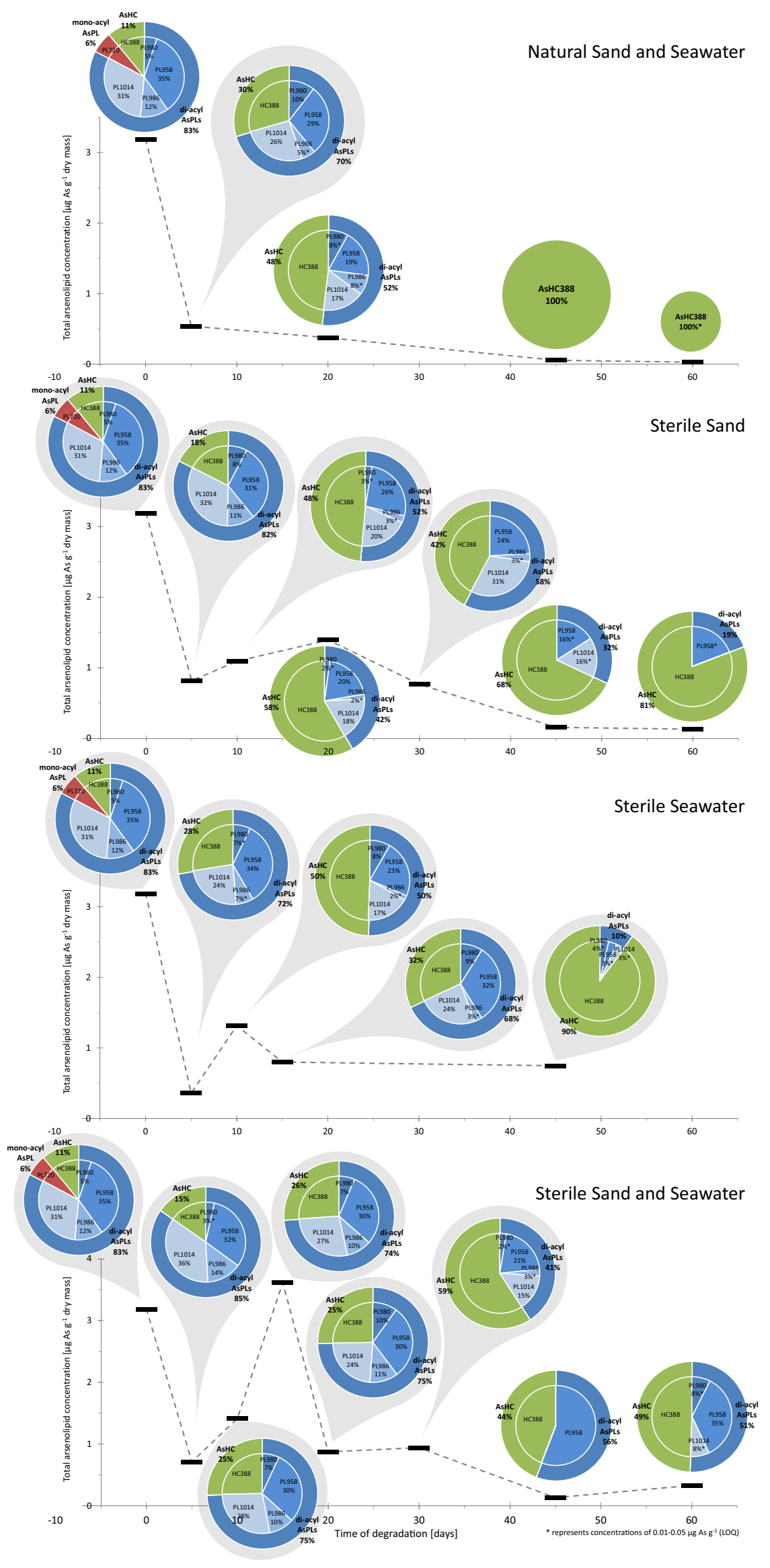


environments. Thus, by day 60 , differences in the overall microbial biomass and activity may have been minimal. Alternatively, the decomposition of $E$. radiata may have been autocatalytic or abiotic in nature (Kolter and Sandhoff 2010; Rontani et al. 2014).

This study is the first to document the arsenolipid species in decomposing marine macroalgae and track the degradation of arsenolipid species over time. Overall, the results show that most of the AsPLs species (mono- and di-acylated) are rapidly lost from tissue during the early stages of decomposition especially when detached algae are allowed to settle on the ocean floor. As decomposition proceeds (i.e., within intertidal zones or on the ocean floor), AsPLs are further degraded; and over time, they are lost completely from algal tissues. AsHC388, however, appears to be more persistent although reasons for this are currently uncertain. Further research is thus required to fully understand and characterize the arsenolipid degradation pathways that occur in marine environments.

Acknowledgments The authors would like to acknowledge the assistance of the 2012 undergraduate Ecochemistry students from the University of Canberra who assisted with the collection and preparation of E. radiata samples. The authors thank Sophy Hart, Liz O'Connor and Martin Campbell who assisted with the E. radiata degradation microcosm preparation, experimentation, and sample preparation as part of the 2011 Resource Science Project Unit at the University of Canberra. We also thank the Austrian Science Fund (FWF) project number I2412B21 for financial support, and NAWI-Graz for supporting the Graz Central Lab-Metabolomics.

Funding Information Open access funding provided by University of Graz.

Open Access This article is distributed under the terms of the Creative Commons Attribution 4.0 International License (http:// creativecommons.org/licenses/by/4.0/), which permits unrestricted use, distribution, and reproduction in any medium, provided you give appropriate credit to the original author(s) and the source, provide a link to the Creative Commons license, and indicate if changes were made.

\section{References}

Al Amin MH, Xiong C, Glabonjat RA, Francesconi KA, Oguri T, Yoshinaga J (2018) Estimation of daily intake of arsenolipids in Japan based on a market basket survey. Food Chem Toxicol 118: 245-251

Amayo KO, Raab A, Krupp EM, Gunnlaugsdottir H, Feldmann J (2013) Novel identification of arsenolipids using chemical derivatizations in conjunction with RP-HPLC-ICPMS/ESMS. Anal Chem 85: 9321-9327

Amayo KO, Raab A, Krupp EM, Feldmann J (2014) Identification of arsenolipids and their degradation products in cod-liver oil. Talanta 118:217-223

Duncan EG, Maher WA, Foster SD, Krikowa F, Mikac KM (2014a) The degradation of arsenoribosides from Ecklonia radiata tissues decomposed in natural and microbially manipulated microcosms. Environ Chem 11:289-300
Duncan EG, Maher WA, Foster SD, Mikac KM, Krikowa F (2014b) The influence of bacteria on the arsenic species produced by laboratory cultures of the marine phytoplankton Dunaliella tertiolecta. J Appl Phycol 26:2129-2134

Duncan EG, Maher WA, Foster SD, Krikowa F (2014c) Total arsenic concentrations and arsenic species present in naturally decomposing Ecklonia radiata tissues collected from various marine habitats. J Appl Phycol 26:2193-2201

Duncan EG, Maher WA, Foster SD (2015) Contribution of arsenic species in unicellular algae to the cycling of arsenic in marine ecosystems. Environ Sci Technol 49:33-50

Edmonds JS, Francesconi KA (2003) Organoarsenic compounds in the marine environment. In: Craig PJ (ed) Organometallic compounds in the environment, 2nd edn. Wiley, Hoboken, pp 196-222

Edmonds JS, Francesconi KA, Hansen JA (1982) Dimethyloxarsylethanol from anaerobic decomposition of brown kelp (Ecklonia radiata): a likely precursor of arsenobetaine in marine fauna. Experientia 38:643644

Foster SD, Maher WA (2016) Arsenobetaine and thio-arsenic species in marine macroalgae and herbivorous animals: accumulated through trophic transfer or produced in situ? J Environ Sci 49:131-139

Francesconi KA, Edmonds JS (1998) Arsenic species in marine samples. Croat Chem Acta 71:343-359

García-Salgado S, Raber G, Raml R, Magnes C, Francesconi KA (2012) Arsenosugar phospholipids and arsenic hydrocarbons in two species of brown macroalgae. Environ Chem 9:63-66

Glabonjat RA, Raber G, Jensen KB, Ehgartner J, Francesconi KA (2014) Quantification of arsenolipids in the certified reference material NMIJ 7405-a (Hijiki) using HPLC/mass spectrometry after chemical derivatization. Anal Chem 86:10282-10287

Glabonjat RA, Raber G, Jensen KB, Guttenberger N, Zangger K, Francesconi KA (2017) A 2-O-methylriboside unknown outside the RNA world contains arsenic. Angew Chem Int Ed Eng 56: 11963-11965

Glabonjat RA, Ehgartner J, Duncan EG, Raber G, Jensen KB, Krikowa F, Maher WA, Francesconi KA (2018) Arsenolipid biosynthesis by the unicellular alga Dunaliella tertiolecta is influenced by As/P ratio in culture experiments. Metallomics 10:145-153

Hanaoka K'i, Usui M (2014) Arsenic circulation in marine ecosystems. J Natl Fish Univ 62:169-172

Hanaoka K'i, Nakamura O, Ohno H, Tagawa S, Kaise T (1995) Degradation of arsenobetaine to inorganic arsenic by bacteria in seawater. Hydrobiologia 316:75-80

Kolter T, Sandhoff K (2010) Lysosomal degradation of membrane lipids. FEBS Lett 584:1700-1712

Maher WA, Ellwood MJ, Krikowa F, Raber G, Foster SD (2015) Measurement of arsenic species in environmental, biological fluids and food samples by HPLC-ICPMS and HPLC-HG-AFS. J Anal At Spectrom 30:2129-2183

Morita M, Shibata Y (1988) Isolation and identification of arseno-lipid from a brown alga, Undaria pinnatifida (Wakame). Chemosphere 17:1147-1152

Navratilova J, Raber G, Fisher SJ, Francesconi KA (2011) Arsenic cycling in marine systems: degradation of arsenosugars to arsenate in decomposing algae, and preliminary evidence for the formation of recalcitrant arsenic. Environ Chem 8:44-51

Ojo AA, Onasanya A (2013) Closed anaerobic biotransformation products of organoarsenic compounds in Fucus distichus. ISRN Environ Chem 2013:1-7

Pengprecha P, Wilson M, Raab A, Feldmann J (2005) Biodegradation of arsenosugars in marine sediment. Appl Organomet Chem 19:819 826

Petursdottir AH, Fletcher K, Gunnlaugsdottir H, Krupp E, Kuepper FC, Feldmann J (2015) Environmental effects on arsenosugars and arsenolipids in Ectocarpus (Phaeophyta). Environ Chem 13:21-33 
Raab A, Newcombe C, Pitton D, Ebel R, Feldmann J (2013) Comprehensive analysis of lipophilic arsenic species in a brown alga (Saccharina latissima). Anal Chem 85:2817-2824

Raber G, Raml R, Goessler W, Francesconi KA (2010) Quantitative speciation of arsenic compounds when using organic solvent gradients in HPLC-ICPMS. J Anal At Spectrom 25:570-576

Rahman MA, Hasegawa H, Lim RP (2012) Bioaccumulation, biotransformation and trophic transfer of arsenic in the aquatic food chain. Environ Res 116:118-135

Rontani J-F, Vaultier F, Bonin P (2014) Biotic and abiotic degradation of marine and terrestrial higher plant material in intertidal surface sediments from Arcachon Bay (France): a lipid approach. Mar Chem 158:69-79

Rumpler A, Edmonds JS, Katsu M, Jensen KB, Goessler W, Raber G, Gunnlaugsdottir H, Francesconi KA (2008) Arsenic-containing long-chain fatty acids in cod-liver oil: a result of biosynthetic infidelity? Angew Chem Int Ed Eng 47:2665-2667

Santosa SJ, Wada S, Tanaka S (1994) Distribution and cycle of arsenic compounds in the ocean. Appl Organomet Chem 8:273-283

Sele V, Sloth JJ, Lundebye A-K, Larsen EH, Berntssen MHG, Amlund H (2012) Arsenolipids in marine oils and fats: a review of occurrence, chemistry and future research needs. Food Chem 133:618-630
Taleshi MS, Jensen KB, Raber G, Edmonds JS, Gunnlaugsdottir H, Francesconi KA (2008) Arsenic-containing hydrocarbons: natural compounds in oil from the fish capelin, Mallotus villosus. Chem Commun 39:4706-4707

Taleshi MS, Seidler-Egdal RK, Jensen KB, Schwerdtle T, Francesconi KA (2014) Synthesis and characterization of arsenolipids: naturally occurring arsenic compounds in fish and algae. Organometallics 33: 1397-1403

Viczek SA, Jensen KB, Francesconi KA (2016) Arsenic-containing phosphatidylcholines: a new group of arsenolipids discovered in herring caviar. Angew Chem Int Ed Eng 55:5259-5262

Yu X, Xiong C, Jensen KB, Glabonjat RA, Stiboller M, Raber G, Francesconi KA (2018) Mono-acyl arsenosugar phospholipids in the edible brown alga Kombu (Saccharina japonica). Food Chem 240:817-821

Publisher's note Springer Nature remains neutral with regard to jurisdictional claims in published maps and institutional affiliations. 